\title{
Avarice: Signs of threats to credible higher education?
}

Indications of the extent to which higher education is becoming 'commercialised' - driven in a variety of ways by avarice and mostly impelled by external interests (including ranking systems which are not discussed here) - are all around us.

At an individual level, it is evidenced by academics who are committed more to their own interests than those normally associated with scientific practice and the importance of the public good. This avarice takes two forms. Firstly, for individuals, it is the substitution of scientific integrity with personal promotion and subsidy income - evidenced by increases in plagiarism, the publication of research articles in predatory journals (at great expense and without scientific substance or credibility), and the delivery of papers at predatory conferences. Secondly, this individual level of operation serves to fuel the profits of predatory journals and the organisers of predatory conferences.

In 2015, Thomas and De Bruin ${ }^{1}$ revealed, in this journal, that plagiarism, driven by a scramble for subsidy payments, was widespread in South African management journals. These authors estimated that the cost to the Department of Higher Education and Training amounted to some ZAR7 million in subsidies paid for unoriginal research. In their paper, Thomas and De Bruin cite a much earlier paper, published in this journal in 2003, titled 'The good, the bad, and the ugly'2, which includes a definition of scientific 'misconduct':

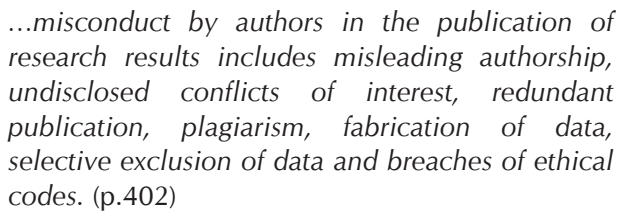

Almost all such misconduct is driven by self-interest rather than the advancement of science.

Since 2003, further indications of the potential for avarice have emerged, most notably predatory journals and, in the past few years, predatory conferences. Mouton and Valentine ${ }^{3}$ have shown just how widespread resorting to predatory journals has become to publish low-quality, often unreviewed or poorly reviewed, research. Their paper reveals that 4245 articles were published in possibly or clearly predatory journals between 2005 and 2014, with a sharp uptick in 2011 leading to a total of 846 such publications in 2014. Notably, the universities with the highest numbers of publications in predatory journals are those with still-developing research histories, including universities of technology.

\section{Predatory conferences}

do not fulfill the purposes of academic conferences...or mislead attendees about details such as peer review, the for-profit status of the organizers, or the expected number of attendees. ...Predatory conferences cut corners by failing to provide proper editorial oversight, for example, by skipping the promised peer review. Some will tout big-name speakers who are not actually involved in the conference. ${ }^{4}$

Predatory conferences typically also charge substantial attendance fees, with the proceeds going primarily to the organisers. Like many academics, I have been asked frequently to deliver papers at 'high-profile' conferences on subjects about which I know little or nothing!

These forms of profiteering are abetted by varying degrees of misconduct and the pursuit of status and subsidies - representing the 'bad and the ugly' in science and higher education. In so doing, they undermine the credibility of institutions and research - credibility that is very difficult to win back once lost.
At a different level, there are other - more direct - ways in which higher education faces the risks created by profiteering: primarily (and sadly) in the private post-school education sector. The Council for Higher Education, which accredits (or does not accredit) courses, receives applications from a growing number of private higher education institutions in South Africa. These institutions (125 registered or provisionally registered in 2016) range in size from the very small to the very large and serve the educational needs of growing numbers of students. Just under 2 million students were registered in universities and technical and vocational education and training (TVET) colleges at the beginning of last year, of whom $12 \%$ were studying in private institutions.

The figure in countries in similar stages of growth as South Africa is often closer to $20 \%$ and it is possible that uncertainty in the public higher education sector could see the local figure rise to similar levels. And while some institutions offer sound education (and training), others are borderline profit-making operations - as attested by the observation that, by 2016, 72 private institutions had their registrations cancelled, a further 7 were added to the list in 2016, and 10 requested that their registrations be discontinued - a total of 89 institutions.

But the pressure will also begin to rise in the public institutions: at present, just over a third of institutional income is generated by student fees (the state contribution having decreased from $49 \%$ to $39 \%$ between 2000 and 2015) and if the fee income is reduced, and state spending remains even at present levels, it will be third-stream income that has to be increased. And that is commercial income in various forms.

Amongst the most egregious examples of private higher education institutions that fail to deliver credible education (or any education at all) are found in the USA. Donald Trump's private university in San Diego was ordered to pay USD25 million to aggrieved students, and there was a threat that Trump might be tried on criminal racketeering charges. Betsy DeVos, Trump's Education Secretary (who understands little about education) has hired as a special advisor Robert Eitel, formerly Chief Compliance Officer (and Vice President) for Bridgeport Education Inc., a for-profit private institution which has faced (and faces) multiple government investigations, the closure of one of its campuses and a settlement of USD30 million because of deceptive student lending. In a decision equally inspired by high levels of corporate integrity, DeVos has appointed Julian Schmoke to head her office that oversees fraud. Schmoke was, until his appointment to government, a Dean at DeVry University which recently settled a USD100 million lawsuit for misleading students. A case of appointing commercial wolves to take care of the public sheep.

There are aspects of the commercialisation of discoveries that are undoubtedly essential to the survival of all universities - but those that are directed at personal gain, profiteering or fraud (directed at students or those who gradually come to direct practices in research and teaching) are certainly potential threats to the broader credibility of higher education.

\section{References}

1. Thomas A, De Bruin GP. Plagiarism in South African management journals S Afr J Sci. 2015;111(1/2), Art. \#2014-0017, 3 pages. http://dx.doi. org/10.17159/sajs.2015/20140017

2. The good, the bad, and the ugly. S Afr J Sci. 2003;(9/10):402-403.

3. Mouton J, Valentine A. The extent of South African authored articles in predatory journals. S Afr J Sci. 2017;113(7/8), Art. \#2017-0010, 9 pages. http://dx.doi.org/10.17159/sajs.2017/20170010

4. Zepernick J, Musick C. How to avoid predatory conferences. Think Science. 2017 July 26. Available from: https://thinkscience.co.jp/en/articles/avoidingpredatory-conferences.html 